\title{
Streptomyces thinghirensis sp. nov., isolated from rhizosphere soil of Vitis vinifera
}

\section{Correspondence \\ Y. Ouhdouch \\ ouhdouch@ucam.ac.ma}

\author{
S. Loqman, ${ }^{1,2}$ B. Bouizgarne, ${ }^{3}$ E. Ait Barka, ${ }^{2}$ C. Clément, ${ }^{2}$ M. von Jan, ${ }^{4}$ \\ C. Spröer, ${ }^{4}$ H.-P. Klenk ${ }^{4}$ and Y. Ouhdouch ${ }^{1}$
}
${ }^{1}$ Laboratoire de Biologie et Biotechnologie des Microorganismes, Faculté des Sciences Semlalia, Université Cadi Ayyad, B.P S-2390, Marrakech, Morocco
${ }^{2}$ Laboratoire de Stress, Défense et Reproduction des Plantes, B.P 1039-51687, Université Champagne Ardenne, Reims, France
${ }^{3}$ Equipe de Lutte Intégrée, Laboratoire de Biotechnologie Végétale et Valorisation des Ressources Naturelles, Faculté Sciences, Université Ibn Zohr, Agadir, Morocco
${ }^{4}$ DSMZ German Collection of Microorganisms and Cell Cultures, Inhoffenstraße 7B, D38124 Braunschweig, Germany

\begin{abstract}
A novel actinomycete, strain $\mathrm{S}_{10} 0^{\top}$, was isolated from rhizosphere soil of wild Vitis vinifera in Thinghir, Ouarzazate Province, Southern Morocco. The taxonomic status of this strain was established using a polyphasic approach. Strain $\mathrm{S} 10^{\top}$ had white-grey aerial mycelium with long, spiral spore chains bearing smooth surfaced spores and produced a yellow diffusible pigment. Chemotaxonomic analyses showed that the cell wall of strain $\mathrm{S} 10^{\top}$ contained LL-diaminopimelic acid and glycine. Phylogenetic analysis based on the almost complete 16S rRNA gene sequence indicated that strain $\mathrm{S} 10^{\top}$ belonged to the Group I streptomycetes, branching off next to Streptomyces marokkonensis LMG $23016^{\top}$ from the Streptomyces violaceoruber group. DNADNA relatedness and phenotypic data distinguished strain $S 10^{\top}$ from the phylogenetically closest related type strains. It is therefore proposed that strain $\mathrm{S} 10^{\top}\left(=\mathrm{CCMM} \mathrm{B}^{\top} 5^{\top}=\mathrm{DSM} 41919^{\top}\right)$ represents the type strain of a novel species of the genus Streptomyces, for which the name Streptomyces thinghirensis sp. nov. is proposed.
\end{abstract}

Over the past decades, interest in the discovery of new sources of secondary metabolites with applications in medicine (Newman et al., 2003) and agriculture (Copping \& Menn, 2000) has significantly increased. Micro-organisms are an almost unlimited source of novel compounds. Among them, actinomycetes hold a prominent position due to their ability to produce various secondary metabolites, including antibiotics (Lazzarini et al., 2000; Watve et al., 2001; Donadio et al., 2002), antitumour agents (Maskey et al., 2003) and enzymes (Breccia et al., 1995; Ko et al., 2005). Actinomycetes are Gram-positive, aerobic bacteria. They form branching substrate and aerial mycelia that bear spores and possess DNA with a high $\mathrm{G}+\mathrm{C}$ content. Many species of the genus Streptomyces are known to produce antibiotics (Chun et al., 1997; Labeda et al., 1997). Actinomycetes represent a high proportion of the soil microbial biomass and appear to be of importance

The GenBank/EMBL/DDBJ accession number for the $16 \mathrm{~S}$ rRNA gene sequence of strain $S 10^{\top}$ is FM202482.

Micrographs showing spore chains and the spore shape of Streptomyces thinghirensis sp. nov. and a table detailing the fatty acid pattern of the novel strain and closely related species of the genus Streptomyces are available with the online version of this paper. among the microbial flora of the rhizosphere (Sardi et al., 1992). Associations between actinomycetes and plant organs can be deleterious or beneficial for the host. While some actinomycetes secrete herbicidal compounds (Tanaka \& Omura, 1993) or cause plant diseases (Locci, 1994), others can fix atmospheric nitrogen symbiotically (Oakley et al., 2004) or protect plants against fungal infections (Cao et al., 2005). Several descriptive reports have shown that actinomycetes are a promising group of fungus-antagonistic and root-colonizing microbes. They protect several different plants from soil-borne fungal pathogens to various degrees (El-Tarabily \& Sivasithamparam, 2006).

In the course of our screening programme for actinomycetes from Moroccan habitats that are active against many phytopathogens (Loqman et al., 2009), one actinomycete strain, strain $\mathrm{S} 10^{\mathrm{T}}$, was isolated from the rhizosphere soil of wild, healthy Vitis vinifera plants, collected from Thinghir, Ouarzazate Province, Southern Morocco. The strain was identified using a polyphasic approach.

Strain $S 10^{\mathrm{T}}$ was isolated on soil extract agar as described in Ouhdouch et al. (2001). The strain was maintained on 
International Streptomyces Project (ISP) no. 2 (ISP 2) agar slants (glucose-yeast extract-malt extract agar) at $4{ }^{\circ} \mathrm{C}$ and as $20 \%(\mathrm{v} / \mathrm{v})$ glycerol stocks at $-20{ }^{\circ} \mathrm{C}$. Biomass for chemical and molecular studies was obtained by growing strain $S 10^{\mathrm{T}}$ in shake flasks in ISP 2 broth $\left(28{ }^{\circ} \mathrm{C}, 1\right.$ week, 150 r.p.m.).

Physiological characteristics were determined after 2 weeks growth at $28{ }^{\circ} \mathrm{C}$ according to the methods prescribed by the ISP (Shirling \& Gottlieb, 1966). Morphological properties were examined by light microscopy and scanning electronic microscopy. The colour of the aerial mycelium was determined from mature sporulating aerial mycelia according to the scale adopted by Prauser (1964) and the colour series was determined according to the system proposed by Nonomura (1974). Production of melanoid pigments was determined on ISP 6 and ISP 7 media. Analysis of cell-wall diaminopimelic acid isomers and whole cell sugars was performed according to the protocol described by Lechevalier \& Lechevalier (1980). Fatty acid methyl esters and mycolic acid trimethylsilylesters were prepared and analysed as previously described (Klatte et al., 1994) using the standard Microbial Identification System (MIDI Inc.) for automated GC analyses (Sasser, 1990).

Carbon source utilization was determined on ISP 9 medium supplemented with sterile carbon sources. Standard techniques were used for the determination of catalase, oxidase and nitrate reduction activities. Sensitivity to $\mathrm{NaCl}$ was established according to the method of Tresner et al. (1968). The temperature range for growth was determined on ISP 2 and Bennett medium (Jones, 1949). Antibiotic resistance was examined by the disc diffusion method on Olson's medium (Olson, 1968) with plates incubated at $28{ }^{\circ} \mathrm{C}$ for $21 \mathrm{~h}$. The antimicrobial activity of strain $S 10^{\mathrm{T}}$ was determined by the plate diffusion method (Bauer et al., 1966). Bacterial test strains were incubated on nutrient agar at $37{ }^{\circ} \mathrm{C}$ for $24 \mathrm{~h}$ and fungal strains were incubated on Sabouraud agar medium at $28{ }^{\circ} \mathrm{C}$ for $24 \mathrm{~h}$ for yeasts and $48 \mathrm{~h}$ for moulds.

For $16 \mathrm{~S}$ rRNA gene sequence analysis, strain $\mathrm{S}^{\mathrm{T}}$ was cultivated for 2 days at $28{ }^{\circ} \mathrm{C}$ with agitation in $500 \mathrm{ml}$ flasks containing $100 \mathrm{ml}$ of Hickey-Tresner medium, $1 \mathrm{~g}$ yeast extract $\mathrm{l}^{-1}, 1 \mathrm{~g}$ beef extract $\mathrm{l}^{-1}, 2 \mathrm{~g}$ NZamine $\mathrm{A}^{-1}$, $10 \mathrm{~g}$ dextrin $\mathrm{l}^{-1}, 20 \mathrm{mg} \mathrm{CoCl} 2.6 \mathrm{H}_{2} \mathrm{O} \mathrm{l}^{-1}$ (Hopwood et al., 1985). Biomass was harvested by centrifugation (8000 $g$ for $10 \mathrm{~min}$ ) and washed twice with double-distilled water. Mycelia (200 mg) were used for DNA extraction as described by Liu et al. (2000). The 16S rRNA gene was amplified by PCR using the universal primers PA and PH. Amplification was carried out in $50 \mu \mathrm{l}$ reaction volumes containing $1.5 \mathrm{U}$ of AmpliTaq Gold Taq polymerase (Applied Biosystems), dNTPs (0.25 mM each), $1 \mu \mathrm{M}$ each primer and $100 \mathrm{ng}$ genomic DNA. Reaction conditions were: $97{ }^{\circ} \mathrm{C}$ for $4 \mathrm{~min}$, followed by 35 cycles of $97{ }^{\circ} \mathrm{C}$ for $45 \mathrm{~s}, 52{ }^{\circ} \mathrm{C}$ for $45 \mathrm{~s}$ and $72{ }^{\circ} \mathrm{C}$ for $45 \mathrm{~s}$ and a final incubation at $72{ }^{\circ} \mathrm{C}$ for $10 \mathrm{~min}$. The amplified products were visualized on a $0.8 \%(\mathrm{w} / \mathrm{v})$ agarose gel stained with ethidium bromide. Sequencing reactions were performed by Macrogen. The primers used for sequencing are listed in Coenye et al. (1999). The sequences obtained were compared with sequences present in the public sequence databases as well as with EzTaxon, a web-based tool for the identification of prokaryotes based on 16S rRNA gene sequences from type strains (Chun et al., 2007). BLAST analysis was performed at www.ncbi.nlm.nih.gov.

DNA-DNA hybridization analysis was performed between strain $S 10^{\mathrm{T}}$ and its closest relatives based on the degree of $16 S$ rRNA gene similarity and the inferred phylogeny. DNA-DNA hybridization with the high scoring (in EzTaxon) but ambiguous sequences for Streptomyces almquistii NRRL B-1685 (GenBank accession no. AY999782), Streptomyces althioticus NRRL B-3981 ${ }^{\mathrm{T}}$ (AY999791) and Streptomyces matensis NBRC $12889^{\mathrm{T}}$ (AB184221) was not deemed necessary because of their distant location in the phylogenetic tree (Fig. 1). DNA was isolated using a French pressure cell (Thermo Spectronic) and was purified by chromatography on hydroxyapatite as described by Cashion et al. (1977). DNA-DNA hybridization was performed as described by De Ley et al. (1970), incorporating the modifications described by Huß et al. (1983), using a model Cary 100 Bio UV/VIS-spectrophotometer equipped with a Peltier-thermostatted $6 \times 6$ multicell changer and a temperature controller with in situ temperature probe (Varian), as described by Wayne et al. (1987). All DNA-DNA hybridizations were conducted in duplicate and the reported results give the mean of the two experiments.

For phylogenetic analysis, $16 \mathrm{~S}$ rRNA gene sequences for the type strains of closely related Streptomyces species were retrieved from GenBank, aligned with CLUSTAL w (Larkin et al., 2007), and analysed using the neighbour-joining, maximum-parsimony and maximum-likelihood tools from the PHYLIP package, version 3.6 (Felsenstein, 2005). Phylogenetic trees were visualized using Dendroscope (Huson et al., 2007).

Strain $S 10^{\mathrm{T}}$ had morphological characteristics that were consistent with members of the genus Streptomyces. From light and electron microscopic observations, it was found that strain $\mathrm{S} 10^{\mathrm{T}}$ had Spirales-type spore chains (see Supplementary Fig. S1a in IJSEM Online) with smooth spore surface ornamentation (Supplementary Fig. S1b). The chemotaxonomic characteristics of strain $S 10^{\mathrm{T}}$ supported its classification as a member of the genus Streptomyces. LLDiaminopimelic acid and glycine were detected in the cellwall peptidoglycan. As usually found for streptomycetes, the fatty acid profile was comprised mainly of fatty acids with a length of 14-18 carbon atoms (Lechevalier, 1977), in particular saturated iso- and anteiso-branched chain fatty acids: ai- $\mathrm{C}_{15: 0}(23.7 \%), \mathrm{i}-\mathrm{C}_{16: 0}(19.5 \%)$, ai- $\mathrm{C}_{17: 0}(13.7 \%)$, $\mathrm{i}-\mathrm{C}_{15: 0}(11.0 \%), \mathrm{i}-\mathrm{C}_{17: 0}(6.5 \%)$ and $\mathrm{i}-\mathrm{C}_{14: 0}(2.5 \%)$, with only a few unbranched fatty acids, $\mathrm{C}_{16: 0}(5.6 \%)$, $\mathrm{C}_{15: 0}(2.3 \%), \mathrm{C}_{17: 0}(0.7 \%)$ and $\mathrm{C}_{14: 0}(0.2 \%)$. A compar- 


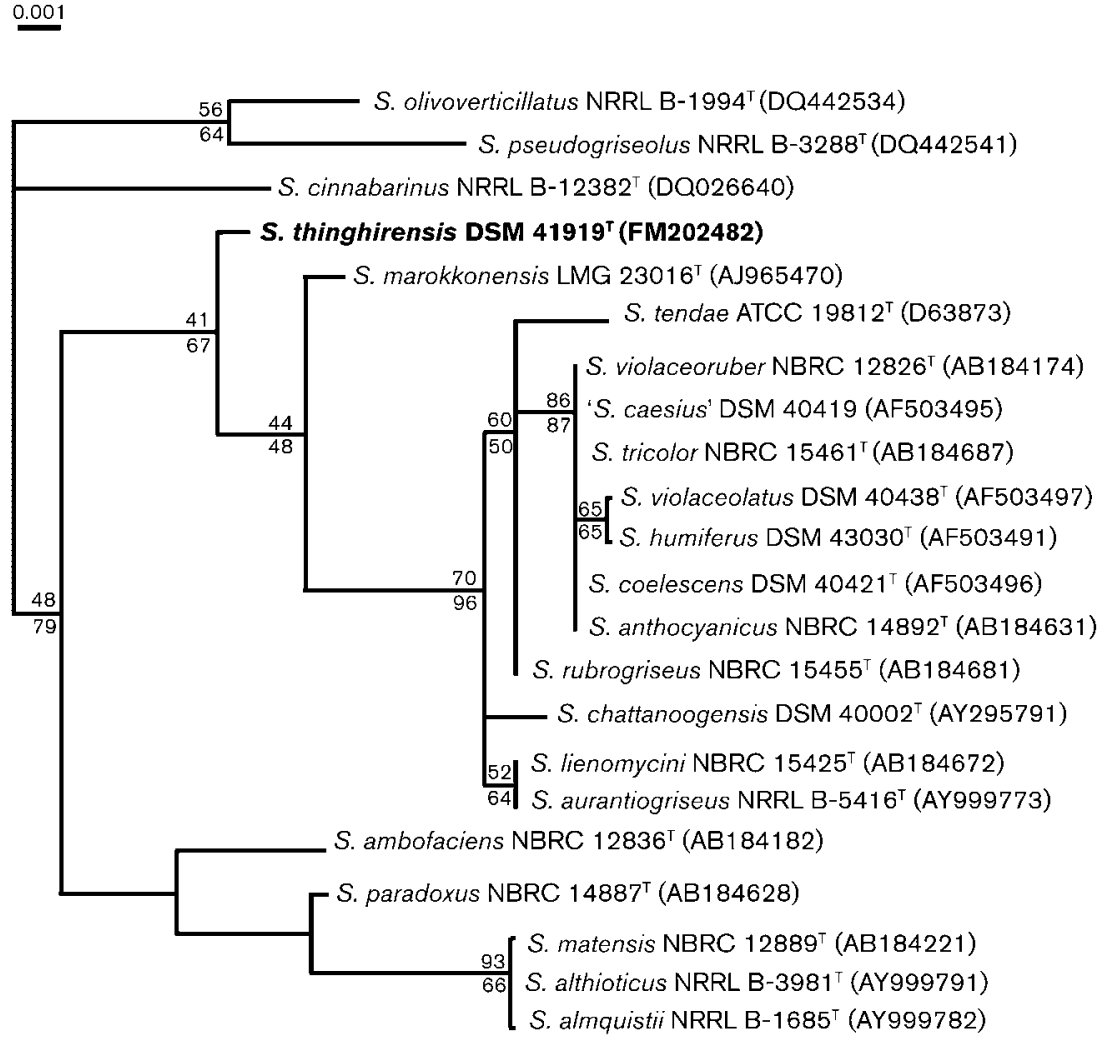

Fig. 1. Unrooted maximum-likelihood phylogenetic tree based on 1436 aligned positions of the 16S rRNA gene showing the phylogenetic relationships between strain $\mathrm{S}_{10}{ }^{\top}$ and the most closely related type strains of the genus Streptomyces. Bootstrap values (\%) above the branches were derived from 1000 replications of maximum-likelihood inferences, those below the branches give the maximum support by 1000 replications of maximum-parsimony, neighbour-joining and least squares ( $\mathrm{FITCH})$ inferences. Bar, 0.001 substitutions per nucleotide position. ison of the fatty acid profiles of strain $S 10^{\mathrm{T}}$ and closely related species is available in Supplementary Table S1 (available in IJSEM Online).

A BLAST search with the 1462 bp $16 \mathrm{~S}$ rRNA gene sequence of strain $\mathrm{S}_{10}^{\mathrm{T}}$ showed that it displayed greater than $99 \%$ sequence similarity to the 16S rRNA gene sequences of many members of the genus Streptomyces. The highest degree of similarity was found with Streptomyces marokkonensis LMG $23016^{\mathrm{T}}$ (99.65\%), S. almquistii NRRL B-1685 ${ }^{\mathrm{T}}$ (99.58\%), S. althioticus NRRL B-3981 ${ }^{\mathrm{T}}$ (99.51\%), S. matensis NBRC $12889^{\mathrm{T}}(99.51 \%)$, Streptomyces aurantiogriseus NRRL B$5416^{\mathrm{T}}(99.32 \%)$, Streptomyces lienomycini NBRC $15425^{\mathrm{T}}$ (99.24\%), Streptomyces coelescens DSM 40421 ${ }^{\mathrm{T}}(99.20 \%)$ and Streptomyces violaceolatus DSM $40438^{\mathrm{T}}(99.18 \%)$. Five of these strains were selected for DNA-DNA hybridization experiments. Low levels of DNA-DNA relatedness to strain $\mathrm{S} 10^{\mathrm{T}}$ were found for all five strains: S. coelescens DSM $40421^{\mathrm{T}}$ $4.6 \pm 0.6 \%$, S. aurantiogriseus DSM $40138^{\mathrm{T}} 6.7 \pm 1.0 \%$, S. lienomycini DSM $41475^{\mathrm{T}} 9.3 \pm 0.3 \%$, S. violaceolatus DSM $40438^{\mathrm{T}} 10.5 \pm 4.5 \%$ and S. marokkonensis DSM $41918^{\mathrm{T}}$ $33.4 \pm 0.4 \%$. When applying the recommended threshold of $70 \%$ DNA-DNA relatedness as proposed by Wayne et al. (1987), strain $S 10^{\mathrm{T}}$ could be differentiated from its five closest neighbours.

Phylogenetic analysis showed that strain $\mathrm{S} 10^{\mathrm{T}}$ was most closely related to Streptomyces marokkonensis LMG $23016^{\mathrm{T}}$ and that both strains branched off separately from the $S$. violaceoruber species group (Fig. 1).
A comparison of the phenotypic characteristics of strain $\mathrm{S} 10^{\mathrm{T}}$ and the strains with the top BLAST results is shown in Table 1. It is clear from these comparisons that strain $S 10^{\mathrm{T}}$ is phenotypically different from the most closely related Streptomyces species. Additional phenotypic properties of the new isolate are given in the species description.

From the phenotypic and genotypic data obtained, it is proposed that strain $S 10^{\mathrm{T}}$ represents a novel species within the genus Streptomyces. The name Streptomyces thinghirensis sp. nov. is proposed with strain $\mathrm{S}^{\mathrm{T}} 0^{\mathrm{T}}$ as the type strain.

\section{Description of Streptomyces thinghirensis sp. nov.}

Streptomyces thinghirensis (thin.ghi.ren'sis. N.L. masc. adj. thinghirensis of Thinghir, named after the town in Southern Morocco where the strain was isolated).

Hyphae are abundant and well-developed. A yellow diffusible pigment is produced on all test media and yellow substrate mycelium and white-grey aerial mycelium are visible. No melanin production is observed on peptoneyeast extract-iron agar (ISP 6) or tyrosine agar (ISP 7). Good growth is observed on ISP 2 agar. Gelatin is not liquefied. Milk is coagulated and peptonized. $\mathrm{H}_{2} \mathrm{~S}$ is not produced. Nitrate is reduced. D-Fructose, D-galactose, Dglucose, D-mannitol, D-mannose, myo-inositol, L-rhamnose and D-sorbitol are utilized as sole carbon sources. DSucrose, maltose, D-lactose and cellobiose are weakly 
Table 1. Physiological characteristics of strain $S 10^{\top}$ and its phylogenetic neighbours

Taxa: $1, \mathrm{~S}_{10}^{\mathrm{T}} ; 2$, S. marokkonensis LMG $23016^{\mathrm{T}} ; 3$, S. coelescens DSM $40421^{\mathrm{T}}$; 4, S. violaceolatus DSM $40438^{\mathrm{T}}$; 5, S. lienomycini DSM $41475^{\mathrm{T}}$; 6, S. aurantiogriseus DSM $40138^{\mathrm{T}}$. +, Well utilized/present; w, weakly utilized; -, not utilized/absent; B, blue; Br, brownish; Cs, colourless; G, grey; GBr, grey-brown; RG, red-grey; WG, white-grey; Y, yellow.

\begin{tabular}{|lcccccc|}
\hline Characteristic & $\mathbf{1}$ & $\mathbf{2}$ & $\mathbf{3}$ & $\mathbf{4}$ & $\mathbf{5}$ & $\mathbf{6}$ \\
\hline Aerial mass colour & $\mathrm{WG}$ & $\mathrm{G}$ & $\mathrm{G}$ & $\mathrm{Br}$ & $\mathrm{G}$ & $\mathrm{RG}$ \\
Substrate mycelium & $\mathrm{Y}$ & $\mathrm{G}$ & $\mathrm{GBr}$ & $\mathrm{Gr}$ & $\mathrm{Cs}$ & $\mathrm{B}$ \\
Reverse side pigment & $\mathrm{Y}$ & - & + & + & - & - \\
Diffusible pigment & + & - & + & + & - & + \\
Melanin pigments & - & - & - & - & + & - \\
Utilization of & & & & & & \\
D-Arabinose & - & $\mathrm{W}$ & + & + & + & + \\
myo-Inositol & + & - & + & - & + & + \\
Lactose & $\mathrm{W}$ & + & - & - & + & + \\
Raffinose & - & - & $\mathrm{w}$ & - & + & + \\
Rhamnose & + & + & + & - & + & + \\
Sucrose & $\mathrm{W}$ & + & + & - & + & + \\
Xylose & - & + & + & + & + & + \\
Degradation of aesculin & + & - & + & + & + & + \\
Growth in 7\% (w/v) & + & + & - & - & + & - \\
NaCl & & & & & & \\
\hline
\end{tabular}

utilized, while D-arabinose, D-xylose and raffinose are not utilized as sole carbon sources. Growth occurs from 28 to $42{ }^{\circ} \mathrm{C}$, from $\mathrm{pH} 5$ to $\mathrm{pH} 10$, and in the presence of $7 \%(\mathrm{w} /$ v) $\mathrm{NaCl}$. Resistant to $\left(\mu \mathrm{g} \mathrm{ml}^{-1}\right)$ : ampicillin (10), amoxicillin (10), nalidixic acid (30), penicillin G (10), sulfamide (25) and rifampicin (5), but sensitive to novobiocin (30), gentamicin (10) and streptomycin (10). Active against the moulds Aspergillus niger, Fusarium oxysporum f. sp. albedinis, Pythium ultimum, Sclerotium rolfsii and Verticillium dahliae, the yeasts Candida albicans, Candida tropicalis and Saccharomyces cerevisiae, and the bacteria Bacillus subtilis, Bacillus cereus, Escherichia coli and Streptomyces scabiei.

The type strain, $\mathrm{S} 10^{\mathrm{T}}\left(=\mathrm{CCMM} \mathrm{B} 35^{\mathrm{T}}=\mathrm{DSM} 41919^{\mathrm{T}}\right)$, was isolated from the rhizosphere soil of wild Vitis vinifera plants.

\section{Acknowledgements}

This work was supported by the Moroccan-Belgium project: FRAB/ CCMM2. We are grateful to Professor Abdelkader Outzoughite (Electron Microscope Unit, Faculty of Science, University Cadi Ayyad, Marrakesch) for his help with scanning electron microscopy observations.

\section{References}

Bauer, A. W., Kirby, W. M., Sherris, J. C. \& Turk, M. (1966). Antibiotic susceptibility testing by standard single disk method. Am J Clin Pathol 45, 493-496.
Breccia, J. D., Castro, G. R., Baigori, M. D. \& Siñeriz, F. (1995). Screening of xylanolytic bacteria using a colour plate method. J Appl Bacteriol 78, 469-472.

Cao, L., Qiu, Z., You, J., Tan, H. \& Zhou, S. (2005). Isolation and characterization of endophytic streptomycete antagonists of Fusarium wilt pathogen from surface-sterilized banana roots. FEMS Microbiol Lett 247, 147-152.

Cashion, P., Holder-Franklin, M. A., McCully, J. \& Franklin, M. (1977). A rapid method for the base ratio determination of bacterial DNA. Anal Biochem 81, 461-466.

Chun, J., Youn, H.-D., Yim, Y.-I., Lee, H., Kim, M. Y., Hah, Y. C. \& Kang, S.-O. (1997). Streptomyces seoulensis sp. nov. Int J Syst Bacteriol 47, 492-498.

Chun, J., Lee, J.-H., Jung, Y., Kim, M., Kin, S., Kim, B. K. \& Lim, Y.-W. (2007). EzTaxon: a web-based tool for the identification of prokaryotes based on $16 \mathrm{~S}$ ribosomal RNA gene sequences. Int J Syst Evol Microbiol 57, 2259-2261.

Coenye, T., Falsen, E., Vancanneyt, M., Hoste, B., Govan, J. R. W., Kersters, K. \& Vandamme, P. (1999). Classification of Alcaligenes faecalis-like isolates from the environment and human clinical samples as Ralstonia gilardii sp. nov. Int J Syst Bacteriol 49, 405-413.

Copping, L. G. \& Menn, J. J. (2000). Biopesticides: a review of their action, applications and efficacy. Pest Manag Sci 56, 651-676.

De Ley, J., Cattoir, H. \& Reynaerts, A. (1970). The quantitative measurement of DNA hybridization from renaturation rates. Eur $J$ Biochem 12, 133-142.

Donadio, S., Carrano, L., Brandi, L., Serina, S., Soffientini, A., Raimondi, E., Montanini, N., Sosio, M. \& Gualerzi, C.-O. (2002). Targets and assays for discovering novel antibacterial agents. J Biotechnol 99, 175-185.

El-Tarabily, K. A. \& Sivasithamparam, K. (2006). Non-streptomycete actinomycetes as biocontrol agents of soil-borne fungal plant pathogens and as plant growth promoters. Soil Biol Biochem 38, 1505-1520.

Felsenstein, J. (2005). PHYLIP (phylogeny inference package) version 3.6. Distributed by the author. Department of Genome Sciences, University of Washington, Seattle.

Hopwood, D. A., Bibb, M. J., Chater, K. F., Kieser, T., Bruton, C. J., Kieser, H. M., Lydiate, D. J., Smith, C. P., Ward, J. M. \& Schrempf, H. (1985). Genetic manipulation of Streptomyces: a laboratory manual. Norwich, UK: John Innes Foundation.

Huson, D. H., Richter, D. C., Rausch, C., Dezulian, T., Franz, M. \& Rupp, R. (2007). Dendroscope: An interactive viewer for large phylogenetic trees. BMC Bioinformatics 8, 460.

Huß, V. A. R., Festl, H. \& Schleifer, K. H. (1983). Studies on the spectrophotometric determination of DNA hybridization from renaturation rates. Syst Appl Microbiol 4, 184-192.

Jones, J. (1949). Fresh isolates of actinomycetes in which the presence of sporogenous aerial mycelia is a fluctuating characteristic. J Bacteriol 57, 141-145.

Klatte, S., Kroppenstedt, R. M. \& Rainey, F. A. (1994). Rhodococcus opacus sp. nov., an unusual nutritionally versatile Rhodococcus species. Syst Appl Microbiol 17, 355-360.

Ko, W. H., Wang, I. T. \& Ann, P. J. (2005). A simple method for detection of lipolytic microorganisms in soils. Soil Biol Biochem 37, 597-599.

Labeda, D. P., Lechevalier, M. P. \& Testa, R. T. (1997). Streptomyces stramineus sp. nov., a new species of the verticillate streptomycetes. Int J Syst Bacteriol 47, 747-753.

Larkin, M. A., Blackshields, G., Brown, N. P., Chenna, R., McGettigan, P. A., McWilliam, H., Valentin, F., Wallace, I. M., Wilm, A. \& other 
authors (2007). CLUSTALW and CLUSTALX version 2. Bioinformatics 23, 2947-2948.

Lazzarini, A., Cavaletti, L., Toppo, G. \& Marinelli, F. (2000). Rare genera of actinomycetes as potential producers of new antibiotics. Antonie van Leeuwenhoek 78, 399-405.

Lechevalier, M. P. (1977). Lipids in bacterial taxonomy - a taxonomist's view. CRC Crit Rev Microbiol 5, 109-210.

Lechevalier, M. P. \& Lechevalier, H. A. (1980). The chemotaxonomy of actinomycetes. In Actinomycetes Taxonomy (Special Publication of the Society for Industrial Microbiology no. A6), pp. 225-292. Edited by A. Dietz \& D. W. Thayer. Arlington, Virginia Society of Industrial Microbiology.

Liu, D., Coloe, S., Baird, R. \& Pedersen, J. (2000). Rapid minipreparation of fungal DNA for PCR. J Clin Microbiol 38, 471.

Locci, R. (1994). Actinomycetes as plant pathogens. Eur J Plant Pathol 100, 179-200.

Loqman, S., Ait Barka, E., Clément, C. \& Ouhdouch, Y. (2009). Antagonistic actinomycetes from Moroccan soil to control the grapevine gray mold. World J Microbiol Biotechnol 25, 81-91.

Maskey, R. P., Li, F., Qin, S., Fiebig, H. H. \& Laatsch, H. (2003). Chandrananimycins A C: production of novel anticancer antibiotics from a marine Actinomadura sp. isolate M048 by variation of medium composition and growth conditions. J Antibiot 56, 622-629.

Newman, D. J., Cragg, G. M. \& Snader, K. M. (2003). Natural products as sources of new drugs over the period 1981-2002. J Nat Prod 66, 1022-1037.

Nonomura, H. (1974). Key for classification and identification of 485 species of the streptomycetes included in the ISP. J Ferment Technol 52, 78-92.

Oakley, B., North, M., Franklin, J. F., Hedlund, B. F. \& Staley, J. T. (2004). Diversity and distribution of Frankia strains symbiotic with Ceanothus in California. Appl Environ Microbiol 70, 6444-6452.
Olson, E. H. (1968). Actinomycetes isolation agar. Detroit, Michigan: Difco Laboratories.

Ouhdouch, Y., Barakate, M. \& Finance, C. (2001). Actinomycetes of Moroccan habitats: isolation and screening for antifungal activities. Eur J Soil Biol 37, 69-74.

Prauser, H. (1964). Aptness and application of colour for exact description of colours of Streptomyces. Z Allg Mikrobiol 10, 95-98.

Sardi, P., Saracchi, M., Quaroni, S., Petrolini, B., Borgonovi, G. E. \& Merli, S. (1992). Isolation of endophytic Streptomyces strains from surface-sterilized roots. Appl Environ Microbiol 58, 2691-2698.

Sasser, M. (1990). Identification of bacteria by gas chromatography of cellular fatty acids, MIDI Technical Note 101. Newark, DE: MIDI Inc.

Shirling, E. B. \& Gottlieb, D. (1966). Methods for characterization of Streptomyces species. Int J Syst Bacteriol 16, 313-340.

Tanaka, Y. \& Omura, S. (1993). Agroactive compounds of microbial origin. Annu Rev Microbiol 47, 57-87.

Thompson, J. D., Higgins, D. G. \& Gibson, T. J. (1994). CLUSTAL W: improving the sensitivity of progressive multiple sequence alignment through sequence weighting, position-specific gap penalties and weight matrix choice. Nucleic Acids Res 22, 4673-4680.

Tresner, H. D., Hayes, J. A. \& Backus, E. J. (1968). Differential tolerance of streptomycetes to sodium chloride as a taxonomic aid. Appl Microbiol 16, 1134-1138.

Watve, M. G., Tickoo, R., Jog, M. M. \& Bhole, B. D. (2001). How many antibiotics are produced by the genus Streptomyces? Arch Microbiol 176, 386-390.

Wayne, L. G., Brenner, D. J., Colwell, R. R., Grimont, P. A. D., Kandler, O., Krichevsky, M. I., Moore, L. H., Moore, W. E. C., Murray, R. G. E. \& other authors (1987). International Committee on Systematic Bacteriology. Report of the ad hoc committee on reconciliation of approaches to bacterial systematics. Int J Syst Bacteriol 37, 463-464. 